\title{
How the new Patent Trial and Appeal Board rules impact the practice of inter partes reviews
}

\section{Patent Analyst}

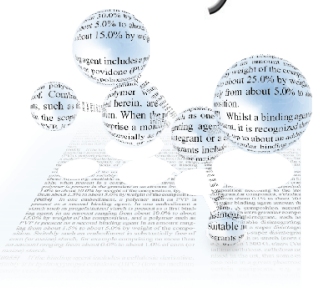

\author{
"...with the new rules, patent owners will have more tools at their \\ disposal to defeat institution of inter partes reviews..."
}

First draft submitted: 26 April 2016; Accepted for publication: 11 July 2016;
Published online: 30 August 2016

Keywords: • inter partes review •IPR • Patent Trial and Appeal Board • PTAB

Congress, as part of the American Invents Act (AIA), enacted the inter partes review (IPR) procedure in 2012. An IPR is a trial proceeding before the United States Patent and Trademark Office (PTO) to review the patentability claims of a patent, but using only prior art consisting of patents or printed publications. Patents covering pharmaceutical products have been, increasingly, under attack by IPR proceedings. Given that there is no standing requirement, hedge funds and so-called public interest groups can readily file a petition for an IPR to invalidate patents owned by pharmaceutical companies.

On 1 April 2016, the PTO published its Amendments to the Rules of Practice for Trials Before the Patent Trial and Appeal Board (PTAB), which amends portions of 37 C.F.R. $\$ 42$ that govern postgrant proceedings, such as IPRs, under the AIA [1]. The new rules become effective on 2 May 2016, and will apply to all AIA petitions filed on or after that date and any ongoing AIA preliminary proceeding or trial before the PTO [2]. To some extent, the new rules 'level the playing field' for patent owners.

\section{Patent owner's preliminary response to petition}

The most impactful change is that the new rules allow patent owners to file new testimonial evidence, such as an expert declaration, with its preliminary response. This change is the most significant because, originally, CFR $\$ 42.107$ did not allow a patent owner to sub- mit an expert declaration in its preliminary response even though the petitioner was able to submit an expert declaration with the IPR petition. There is, however, a caveat to this new rule. If a genuine issue of material fact is created by testimonial evidence, the issue will be resolved in favor of petitioner solely for institution purposes so that petitioner will have an opportunity to cross-examine the declarant during the trial [3]. The factual dispute must be material to the institution decision.

The PTO did not agree with commenters that a patent owner's submission of new testimonial evidence would necessarily create a factual dispute that may not be resolved preinstitution [4]. Acknowledging Federal Circuit law, the PTO made clear that the 'mere existence in the record of dueling expert testimony does not necessarily raise a genuine issue of material fact' [5]. The standard used by the PTO for determining a 'genuine issue of material fact' will be the same standard required to preclude summary judgment as applied by Federal Courts.

A patent owner is not limited to any express number of declarations and will have 3 months to put together a rebuttal expert declaration to file with its preliminary response. In light of the short time period, patent owners should consider lining up experts and collecting evidence in anticipation of IPR proceedings for patents they believe may be targeted.

While a patent owner's rebuttal declaration may preclude institution, a heavily fact-

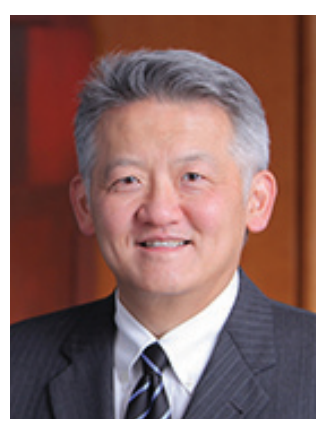

Benjamin C Hsing Author for correspondence: BakerHostetler LLP, 45 Rockefeller Plaza, New York, NY 10111, USA bhsing@bakerlaw.com

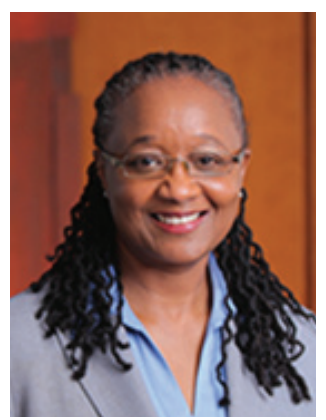

Wanda French-Brown BakerHostetler LLP, 45 Rockefeller Plaza, New York, NY 10111, USA 
based declaration from a petitioner's expert even in the face of a rebuttal declaration would most likely create a genuine issue of material fact, and, thus, support instituting an IPR. As such, the patent owner should consider: treating the preliminary response and any supporting expert declaration like a motion for summary judgment focusing on arguments and opinions based on undisputed facts or facts that are difficult to dispute; the risk, if any, of not submitting a rebuttal expert declaration [6]; strategies going forward after institution when its expert's opinions have already been considered and found unpersuasive to preclude institution and what will persuade the PTAB judges during trial when the petitioner's evidence is not viewed in its most favorable light.

\section{"If the petition lacks substantial merit, it may not make sense strategically to provide an opportunity for the petitioner to cure the defects in its filings."}

\section{Sanctions}

New rule 42.11, which requires a Rule-11 type of certification, would purportedly ensure that practitioners do not file frivolous papers, including IPR petitions. Specifically, the new rule requires practitioners to comply with the certification requirements of CFR $\$$ 11.18(b)(2):

- The paper is not being presented for any improper purpose, such as to harass someone or to cause unnecessary delay or needless increase in the cost of any proceeding before the office;

- The other legal contentions therein are warranted by existing law or by a nonfrivolous argument for the extension, modification or reversal of existing law or the establishment of new law;

- The allegations and other factual contentions have evidentiary support or, if specifically so identified, are likely to have evidentiary support after a reasonable opportunity for further investigation or discovery; and

- The denials of factual contentions are warranted on the evidence, or if specifically so identified, are reasonably based on a lack of information or belief.

The penalties for a violation may include, but are not limited to, any combination of: striking the offending paper; referring a practitioner's conduct to the Director of Enrollment and Discipline for appropriate action; precluding a party or practitioner from submitting a paper, or presenting or contesting an issue; affecting the weight given to the offending paper or terminating the proceedings in the office [7].

The new rule also provides a procedure that allows a party to 'cure' a violation [8]. Before seeking authorization to file a motion for sanctions, the rule requires service of the proposed motion on the other party at least 21 days before seeking such authorization [9]. The receiving party has 21 days to 'cure' the alleged violation [10]. Although requests for sanctions have so far been infrequent in AIA trial proceedings [11], in light of the new rules, there could be an increase in requests for sanctions against petitioners for filing frivolous petitions. Therefore, petitioners should thoroughly conduct a proper investigation of the patent to ensure that the petition is not frivolous and ensure that submissions to the PTAB have merit and are not for an improper purpose. The patent owner should consider whether to seek authorization to file a motion for sanctions bearing in mind that to the petitioner has an opportunity to cure any alleged violations or defects in the petition. If the petition lacks substantial merit, it may not make sense strategically to provide an opportunity for the petitioner to cure the defects in its filings.

\section{Claim construction standard}

The new rules permits a Phillips-type claim construction standard, like the one applied by district courts, but only for IPRs involving patents that will expire before entry of final written decision [12]. The PTO left intact the 'broadest reasonable construction' standard for other patents.

Arguably, the PTAB should use the same claim construction standard as used by the district courts for all patents because many patents involved in an IPR are also in parallel district court litigation with a route of appeal to the same reviewing court, and using a different standard for claim construction could lead to inconsistent outcomes. The PTO, however, contends that applying the broadest reasonable interpretation for a claim is consistent with the office's long-standing practice in postissuance proceedings and encourages clear and unambiguous claim drafting [13]. The PTO does not believe that using differing standards for claim construction in different tribunals presents a scenario where inconsistencies are inappropriate [14]. In Cuozzo Speed Tech., LLC v. Lee, the Supreme Court agreed with the PTO and held that the PTAB was entitled to construe claims according their broadest reasonable interpretation rather than their plain and ordinary meaning (i.e., Phillips-type construction). The Supreme Court also held that the PTO's decision to institute an IPR proceeding is not appealable to the Federal Courts. 


\section{Word count}

The new rules change the limits from a 'page count' to a 'word count'. The PTO amended CFR $\$ 42.24$ to implement a word count limitation for petitions, patent owner preliminary responses, the patent owner responses and petitioner's replies, as set forth below:

- Petition for IPR: 14,000 words (previously limited to 60 pages);

- Patent Owner Preliminary Response: same as word count for petition;

- Patent Owner Response: same as word count for petition;

- Petitioner Reply: 5600 words (previously limited to 15 pages) [15].

Under the new rules, mandatory notices and grounds for standing are exempt from the word count, which were previously included in the page limit. A significant advantage of the word count limit

\section{References}

1 Patent and Trademark Office, Amendments to the Rules of Practice for Trials Before the Patent Trial and Appeal Board, 81 Fed. Reg. Vol. 81, No. 63, at 18750 (April 1, 2016) (to be codified at 37 C.F.R. pt. 42).

281 Fed. Reg. Vol. 81, No. 63, at 18750.

381 Fed. Reg. Vol. 81, No. 63, at 18755.

481 Fed. Reg. Vol. 81, No. 63, at 18755-56.

5 Id. at 18756 (citing Mortgage Grader, Inc. v. First Choice Loans Servs., No. 2015-1415, 2016 WL 362415, at*8 (Fed. Cir. Jan. 20, 2016)).

6 In response to commenters, the PTO made clear that no negative inference would be drawn if a patent owner decides is that parties can include diagrams and illustrations, which are not included in the word count, without the hassle of formatting pages to stay within limits. In conclusion, according to the PTO, it implemented the new rules to ensure fairness and efficiency while meeting all Congressional mandates. However, it appears that, with the new rules, patent owners will have more tools at their disposal to defeat institution of IPRs, thereby resulting in a lower percentage of IPRs being instituted in the future.

\section{Financial \& competing interests disclosure}

The authors have no relevant affiliations or financial involvement with any organization or entity with a financial interest in or financial conflict with the subject matter or materials discussed in the manuscript. This includes employment, consultancies, honoraria, stock ownership or options, expert testimony, grants or patents received or pending, or royalties.

No writing assistance was utilized in the production of this manuscript.

not to present new testimonial evidence with a preliminary response. 81 Fed. Reg. Vol. 81, No. 63, at 18755.

$7 \quad$ See CFR $\$ 11.18(\mathrm{c})(1)-(5)$.

881 Fed. Reg. Vol. 81, No. 63, at 18760.

$9 \quad 81$ Fed. Reg. Vol. 81, No. 63, at 18761.

1081 Fed. Reg. Vol. 81, No. 63, at 18761.

1181 Fed. Reg. Vol. 81, No. 63, at 18761.

1281 Fed. Reg. Vol. 81, No. 63, at 18762.

1381 Fed. Reg. Vol. 81, No. 63, at 18752.

1481 Fed. Reg. Vol. 81, No. 63, at 18752.

1581 Fed. Reg. Vol. 81, No. 63, at 18763. 